\title{
The Resurrection as Near-Death Experience
}

Roger B. Cook, M.A.

\begin{abstract}
I suggest in this paper that Jesus Christ was not clinically dead but in a deep coma when he was taken down from the cross. He was revived by Joseph of Arimathea, who was permitted to take Jesus's body into his care. By Pentecost, seven weeks later, Jesus had finally recovered from his wounds, and his reappearance convinced his followers that he was the Son of God. I suggest that the Resurrection was not a physical happening, but a near-death experience. As such, it was totally real to Christ himself, and it also confirmed his belief that he could, by proxy, discharge humanity's sins.
\end{abstract}

"In the beginning was the Word...." The opening of St. John's Gospel has been a topic of exhaustive debate for centuries. Whatever it means, it certainly put a strong emphasis on communication. It is the words of the New Testament that have endured and influenced the lives, for good or ill, of countless millions. Whether they can be said to form an exact historical record of what happened and what was said 2,000 years ago is arguable, and I express some qualifications on this account below, but it is certain that after persistent repetition and wide dissemination these words have acquired a substantial presence in the life and culture of Western society.

Roger B. Cook, M.A., was until 1991 a lecturer at the Open University, Milton Keynes, England. Reprint requests should be addressed to Mr. Cook at The Old Farmhouse, Steeple Langford, Salisbury, Wilts SP3 4LZ, United Kingdom. 
The words of Jesus himself possess unique importance because he clearly anticipated that the death experience would take a particular form. He also foresaw that his experience would have great significance for the rest of humanity. Stripped of its religious connotations, it corresponded closely to the near-death experiences reported by many people today, with one important difference: Christ saw the experience as underpinning a code of behavior, indeed a way of life, based on forgiveness. As I will show below, the forgiveness so attained is neither a bargaining chip nor a perquisite received in return for leading a blameless life; it formed both the core of his religious philosophy and a central element of the final experience.

To suggest that Christ was not a divine being is to devalue his status as the Son of God, as well as to confront the problem of what "divinity" really means. However, problems of definition need not invalidate the essential thrust of his teaching, which may be summarized as attaining forgiveness for one's faults, so that the guilt and remorse they evoke do not overwhelm and finally obliterate the intense joy of the final experience.

Before considering the implications of such a view, I intend to argue four things: (1) that Christ was not dead when he was taken down from the cross; (2) that he was entombed while in a coma; (3) that he recovered and was nursed back to health; and (4) that none of these facts invalidates his claim-also the central tenet of the Christian religion-that by dying he would save men and women from punishment for their sins.

\section{Evidence That Jesus Had a Near-Death Experience}

\section{Evidence That Christ Did Not Die on the Cross}

The usual Roman practice was for a victim of crucifixion to be dispatched by having his legs broken. This would result in his whole weight hanging by the arms, since he would be deprived of the means by which he could push himself up, thus allowing his lungs to expand. No longer able to support his body weight in order to breathe, the victim died very quickly from asphyxiation. But in Christ's case, the Roman official responsible for seeing that the criminals were dead stayed the hands of those who had already broken the legs of the other two victims. 
Christ was removed from the cross without having his legs broken because he had become lifeless by the criterion that prevailed at that time: he did not appear to be breathing. The significance of the heartbeat was not understood at that time. The apparent absence of breathing was considered sufficient evidence of death, but a spear thrust into the chest was a recognized means of making certain that the "breath of life" had left the body. In Christ's case it seemed to have had the effect of draining a pleural effusion, a mixture of blood and water, possibly the consequence of his having been scourged.

These facts were recorded by the witness whose testimony formed important parts of St. John's Gospel. Although this Gospel is considered more a theological account than a purely historical record, it included a number of significant events that come across with remarkable authenticity. The writer broke into the narrative in order to emphasize the actuality of what he had witnessed:

But when they came to Jesus, they found that he was already dead, so
they did not break his legs. But one of the soldiers stabbed his side
with a lance, and at once there was a flow of blood and water. This is
vouched for by an eye-witness, whose evidence is to be trusted. He
knows that he speaks the truth, so that you too may believe. (John
19:33-36)

The Roman centurion had witnessed Jesus "giving up the ghost"; indeed, he is on record in the Synoptic Gospels as having been greatly impressed by Christ's bearing, and perhaps that is why he chose to spare Jesus the humiliation of having his legs broken.

\section{Evidence that Christ Was Entombed While in a Coma}

Terrible though Jesus's wounds were, none were mortal. He had been conscious on the cross for a relatively short time. In Roman crucifixions, death rarely occurred before 36 hours had elapsed, and on occasion took as long as 9 days (Douglas, 1982). Jesus appeared to have been fully conscious on the cross for only 3 hours before lapsing into unconsciousness quite abruptly:

A jar stood there full of sour wine; so they soaked a sponge with wine, fixed it on a javelin, and held it up to his lips. Having received the wine, he said, "It is accomplished!" He bowed his head and gave up his spirit. (John 19:29-30) 
It is quite possible that in his weak condition he gagged on the bitter liquid and lapsed into a coma. The rapidity of his apparent passing surprised Pontius Pilate, who according to one Gospel asked the centurion to confirm it. Jesus then remained on the cross for about 3 hours until Joseph of Arimathea, having obtained permission to bury the body, came to carry it away to his own private sepulchre.

The circumstantial evidence for Jesus being in a coma is reasonably coherent and the theory has circulated for a very long time. However, it has foundered in the past on two counts. First, it is inconceivable that he should have recovered the strength needed to remove the stone that sealed his tomb; and second, if he had then met the Disciples they would have seen a physical wreck in need of urgent medical attention, not their familiar leader and source of inspiration.

\section{Evidence of Christ's Return to Health}

Rodney Hoare (1984) has suggested that Joseph of Arimathea and Nicodemus discovered Jesus to be still alive when they began to prepare his body for laying out in Joseph's sepulchre, and that they then carried him away and took care of him until he was fully restored to health. In his subsequent encounters with his Disciples he was therefore a man of flesh and blood, not a spirit.

This version of events ties in closely with the Gospel account, at least up to the point at which the body of Jesus was lying in the sepulchre. Thereafter the Gospels conflict about what happened when the tomb was found to be empty, and about when and where Jesus appeared to his Disciples. But one definite chronological fact is that he was crucified at Passover and that the Disciples, fired with the certainty that they had seen their risen leader, triumphantly proclaimed his Resurrection at Pentecost, seven weeks after Passover. In these intervening seven weeks Jesus could have been restored to health and made the journeys to Emmaus and Galilee.

The most problematic aspect of this version of events, which apart from disparities over chronology fits very well with the Gospel accounts, is that no evidence has ever come to light about the subsequent years of Jesus's life. But there are good reasons why he should want to take no further part in spreading the message of the Gospel, indeed why he should want to avoid contact of any kind with his family or Disciples.

First, his near-death experience would have shown him that though his premonitions had been valid, and his "death" and resurrection had 
taken place, they had not taken a physical form but had involved his inner self. Yet his claims had been abundantly vindicated: he had asserted that if one genuinely asked for God's forgiveness for harming others, one would not spend eternity-the product of one's dying moments -in the anguish of punishment that the devout Jew believed would be his fate. He had gone through all the stages of a near-death experience, including the encounter with a Being of Light; His predictions had been triumphantly vindicated.

Second, he must have known that his Disciples were making a tremendous stir in the land as they went about proclaiming his Resurrection. One can only speculate as to both his reactions and his plans for the rest of his life in such a situation. But withdrawal into anonymity or obscurity would seem a very logical option: he had nothing more to add, either in deeds or words, to the message of salvation and redemption. What he had achieved would be completely destroyed if the High Priests and the Pharisees managed to get hold of him. Roman efficiency and Jewish zealotry would not have been cheated of their prey a second time.

In fact his behavior was entirely consistent with a desire to show his followers that he had survived death, while at the same time keeping clear of the authorities. He displayed his wounds and broke bread with the Disciples on more than one occasion, yet he seemed to have managed the encounters in such a way that he could slip away without them following. He left them kneeling-"in the act of blessing he parted from them" (Luke 24:51)-or stayed only long enough to be recognized, as in the supper at Emmaus, and was assisted by their very natural awe: "None of the Disciples dared to ask 'Who are you?' "(John 21:12)

The most unsatisfactory aspect of this version is the contrast between the vividness and immediacy of the Gospel version of events up to and including the crucifixion and the scarcity of equally reliable information thereafter. Coupled with this is the perception that Joseph of Arimathea could hardly have kept Jesus so well hidden that no hint of his continued existence would have leaked out. However, on this reading Joseph and Nicodemus would have been the only two people to have known the truth about Christ's "death" on the cross and return to the world from a near-death experience. Both would have had to guard that secret with their lives, for at least three reasons.

In the first place, they had flagrantly perverted the due process of Roman law. Second, they had defiled themselves by meddling with that unclean thing, a dead body, which to add to their disgrace was that of a convicted felon. Third, they would forfeit all their pre- 
eminence in the councils of the mighty if they were known to have had dealings with the dangerous sect founded by the dissident and troublemaker, Jesus Christ.

Hoare (1984) made the point that the sociocultural gulf between Joseph of Arimathea and the class from which Jesus and the Disciples came was vast to the point of unbridgeability. Joseph was a member of the Sanhedrin and Nicodemus was said in the Talmud to have been so rich he could have fed the entire population of Israel for eight days. Jesus's followers, at the extreme other end of the social scale, would have had no way of learning about his restoration to health in the dwellings of the mighty.

So discouraged were his friends and family that they quickly left Jerusalem after the crucifixion and dispersed. The impression one receives is that Jesus felt the need to seek them out and show himself at a number of locations, such as by the Sea of Tiberius and on the road to Emmaus. He could do no more than make it plain that he had conquered death, and in doing so borne the sins of the Jewish people; it was for others to carry the message to the world at large.

\section{Validation of Jesus's Claims}

Jesus's near-death event, if it took place as described here, did at least keep within the compass of the laws of nature as we know them: a man was tortured and nailed to a cross, fell into a deep coma and was taken away to be restored to health. Although awful to contemplate, no aspect of this interpretation need be unduly hard to believe. Resuscitation techniques have made returning from the frontier of death a relative commonplace today. But at that time, Jesus's experience was, as far as we know, unusual. Moreover, it happened to an unusually remarkable man.

Assuming that the near-death experience is as universal as current research tends to indicate, Jesus would seem to have penetrated the death process as far as the final frontier: the encounter with loved ones and a Being of Light. Any doubts he felt-and we know from the heartfelt cry "My God, My God, why hast thou forsaken me!" that he had one terrible moment of doubt-would have been totally annihilated when he embarked on the near-death experience.

\section{Implications of Jesus's Near-Death Experience}

There are three aspects of Jesus's near-death experience I will elaborate below. First are the premonitions he had about the manner of his 
death. Most of these relate to the fulfillment of Old Testament prophecies and clearly have considerable significance for the convinced Christian, but they also have a logical framework quite independent of their religious connotations. Second, I will explore the evidence from the Gospels and reports in the Acts of the Apostles for the light they can throw on his near-death experience. Third and finally, I intend to show that Jesus's message was consistent both with his particular perception of death and the near-death experience as commonly understood today.

\section{Premonitions}

One remarkable attribute of Jesus was his exhaustive knowledge of Jewish law and Scripture. It is easy to underestimate the weight and authority of this learning when it is set beside our burgeoning modern understanding of natural laws, and the consequent growth of science and technology that informs all aspects of life in the twentieth century. In first century Israel, however, all scientific knowledge was comprehended in "the Law and the Prophets." Jesus's understanding of them was, according to the Gospels, paramount; it was certainly superior to that of the leading Jewish scholars.

The dialogue between Jesus and Nicodemus (John 3:1-21) supplied perhaps the clearest statement of how Jesus saw his role. Nicodemus was the equivalent of a modern skeptic, but with one significant difference: whereas now one would look to science for solutions, the only source of enlightenment in those days was Holy Writ. In his search for truth Nicodemus forced Jesus to confront the underlying implications of his teaching with the question: "How can a man be born when he is old? Can he enter a second time into his mother's womb and be born?"

Jesus, adopting the normal conventions of such a dialogue, couched his answer in phrases derived from Scripture, but it became clear that what he was trying to teach lay beyond his hearer's capacity for understanding. "If you refuse to accept what I say about earthly things," he said, "what chance is there if I tell you about heavenly things?" There then followed the central tenets of his teaching, as they are repeated in the modern Communion service. He could not put his role into words more explicit than those. But their full meaning can only be clear to those who realize that he was describing a near-death experience rather than a return to bodily existence.

The different aspects of the death experience that he referred to during his ministry include these: 
1. punishment and repentance (Matthew 4:17, 5:22-24, 7:1-2, 9:12-13, 11:20-24, 12:36, 13:49-50, 18:6, 24:50-51, 25:31-46; Luke 12:58-59, 13:1-5, 15:7, 15:11-32, 24:47; John 3:17, 8:24, 8:34, 9:39);

2. forgiveness and reconciliation (Matthew 5:7, 6:6, 6:18, 7:11, 11:28, 12:31-32, 12:37, 13:49-50, 18:3-4, 18:23-35; 25:31-36; Luke 6:37-38, 7:41-48, 12:58-59, 24:46-47; John 1:29, 5:29, $8: 24,8: 36,12: 47-50,20: 23)$;

3. regeneration, resurrection, and redemption by works (Matthew 5:3-7:27, 6:4, 6:18, 6:20-21, 7:11-14, 7:21, 10:39, 10:42, $11: 28-30,13: 41-43,13: 49,16: 27,18: 23-35,18: 28-30,20: 1-$ $34,22: 30,21: 31-46$; Luke 6:37-38, 9:27, 13:24, 16:1-9; John 2:21-22, 3:3-8, 5:21, 6:38-40, 6:53-58, 7:37-39, 10:17, 11:25, $12: 47,14: 3,17: 1-26,18: 36$ );

4. role as Messiah and light of the world (Matthew 16:27-28, 24:27; Luke 21:25-28; John 3:13-17, 7:16, 7:28, 8:12, 8:16$17,10: 7-9,10: 14-18,11: 27,12: 23,12: 32-33,12: 35-36,12: 46$, $14: 6,14: 1-16: 33,18: 36$;

5. sacrifice and sacrament; role as Lamb of God or scapegoat (John 1:29, 14:1-16:33, 17:14-18);

6. eternity and everlasting life (Matthew 5:1-12, 24:35; Luke 7:28, 20:36-38, 21:32-33, 23:43; John 1:51, 3:16-17, 3:36, $4: 14,6: 27,6: 39-40,6: 47,8: 51,8: 56-58,10: 28,11: 26,12: 25$, $12: 32,16: 33,17: 2-3,17: 24,21: 20-23)$;

7. ineffability (Matthew 13:11-14; John 6:60, 8:31-43);

8. part of life cycle (Matthew 13:31-32; John 3:7-8, 12:24);

9. preparing a place (Matthew 13:43; John 6:44, 12:32, 12:36, 13:36, 14:2-6);

10. duty to evangelize (John 10:16, 15:8, 15:16, 20:23); and

11. timelessness of Last Judgment (Matthew 12:36-37, 24:35-36, 24:42-45, 25:31-46; Luke 21:27-28; John 5:24-30, 6:27, 6:54-58).

Judaism had always been permeated by the belief that obedience should be inculcated into an erring people; this was to be achieved by divine punishment and reward. Jesus was steeped in Jewish theology and therefore predisposed towards this view. Punishment-the everlasting fire-could in this view only be avoided by renouncing error and experiencing genuine contrition. Jesus therefore must have viewed the death process from this particular perspective. However, near-death experiences more recently reported do not point to eternal 
damnation as an outcome, even for those such as suicides whose "sinful" decision to destroy life might be expected to invite punishment.

It is even conceivable that those with the most damnable sins on their consciences-murderers, child abusers, rapists-may experience a death that is positive and healing in its final stage. The life review, if it forms an element of such a person's death process, is likely to be particularly unpleasant, since it may involve a re-experiencing of the sin and the suffering it caused others. But after that may come reconciliation in the felt presence of a Being of Light.

According to Jewish theology of Christ's time, however, such sin would inevitably bring retribution on the sinner. Jesus perceived himself as the agent by whom this cycle of irrevocable condemnation could be broken. By taking upon himself the role of scapegoat, another characteristic feature of Judaic belief, and adapting it to that of sacrificial lamb, he would bear, by proxy, the sins of every sinner who called on him to do so.

Within such a framework, Jesus's premonitions, prophesies, and "sayings" take on a rational and logical coherence. It was a perspective that he might be said to have inherited from John the Baptist. John proclaimed him as the Lamb of God, who would take away the sin of the world, and also as the promised Messiah. Jesus accepted this role and constantly justified his actions and sayings by reference to the relevant Scriptures. His teachings about death, listed above, can also be read as an exegesis of the New Testament from this perspective, demonstrating that the Gospel message is consistent with the neardeath experience as we understand it today.

\section{Jesus's Near-Death Experience and Its Consequences}

What transpired after Christ's death was an interpretation and reframing by his close followers of his teaching and his biography into a doctrine, and finally a theology, that could account both for his judicial murder and his increasingly delayed second coming. Central to this formulation was the notion that the dead would experience resurrection at the same instant of earthly time.

However, when confronted with the testimony of those who have undergone a near-death experience, the only view of resurrection that makes sense is that the moment of death becomes the resurrection, the day of judgment, the Last Trump, or Armageddon, for that individual. And since death will be the moment of transition into a timeless dimension, the idea of resurrection at the same chronological instant 
becomes meaningless. Shorn of this superfluity, the idea of a final experience shared (in the mind) with the great mass of humankind, past and present, can more reasonably be entertained.

The assumption into the company of all loved ones in the presence of a great white light becomes the central, final, and resolving part of the near-death experience, as I suggest it was for Jesus. Because he understood the significance of what had happened to him, he made every effort to tell the world about it.

But there was a certain mismatch between the evidence of his appearances and the interpretation of them by his followers. Apart from the disparities in chronology noted above, Christ's appearances were almost bound to take on the coloring of the supernatural. His Disciples had seen their beloved leader put to death before their eyes; they had subsequently seen him alive and well. His physicality was emphasized by Doubting Thomas feeling the spear wound in his side. Divine intervention of the Holy Spirit was the only explanation that could effect a match between the events they had experienced and their knowledge of the cycle of life and death.

The last verses of Chapter 20 of John's Gospel implied that not all Jesus's appearances had been included in the Gospel accounts:

There were indeed many other signs that Jesus performed in the presence of his Disciples, which are not recorded in this book. Those here written have been recorded in order that you may hold the faith that Jesus is the Christ, the Son of God, and that through this faith you may possess life by his name. (John 20:30-31)

In the same way that he emphasized the quality of his testimony about Jesus "giving up the ghost," John here seemed to affirm that there were numerous appearances of the resurrected Jesus, but he could not vouch for them personally and hence omitted them.

\section{Consequences}

Jesus's perception was in effect consistent not only with the neardeath experience as it is known today by the millions who have experienced it; it also fitted closely the predictions of the prophets he had 
studied so exhaustively. But it did not fit so neatly with the aspirations of the subject people chafed by the Roman yoke, awaiting a Messiah. The Gospel story is full of incidents wherein he was perceived as what we would today call a guerrilla leader or revolutionary, and was therefore obliged to construe the Scriptures so as to emphasize the essentially spiritual nature of his calling.

But he constantly returned to his theme: if you could obtain forgiveness from whomever you had harmed, your death would not be irretrievably marred by the guilt of your unresolved deed. However, if you were unable to effect a reconciliation, because the person you wronged was already dead or otherwise unreachable, then he, Jesus Christ, would take on the burden of your guilt, provided your contrition was genuine. Your own death might then be free of any harrowing life review, and you would certainly avoid that more lasting outcome of continuing remorse: an eternity in hell.

He may have been wrong about eternal suffering being the lot of those who do not take the opportunity to repent; perhaps it is intrinsic to the nature of the human organism that it will flare into some paradisal experience in its final seconds, regardless of whatever violent inner turmoil of guilt and remorse may have been undergone. But since he was a profoundly religious Jew, punishment was central to his thinking.

The sheer power of Jesus's personality, presence, conviction, and charisma was such as to make a handful of ordinary men, from one subgroup in a not particularly favored colony of one early civilization, strong and sure enough of what they had seen to convince millions of others of the validity of his sayings and doings even though they did not have the full picture. They had witnessed him being put to death, and had subsequently seen him looking just as he had before his execution. That one incredible fact could not be ducked; it is hardly surprising they felt a compulsion to proclaim it to the world at large. In doing so they also gave some account of his miracles and parables, and the wisdom and compassion he had shown.

If one opts for the explanation that the crucifixion ended in a neardeath experience, there need be nothing irrational in commemorating Christ's death and redemption after, say, the manner sanctified by the Church; that is a personal choice. Whether the solution he devised can be said to have had divine inspiration is a matter for debate by those who would ascribe a specific meaning to the word "divine." But the fact remains that Christ's interpretation was, and in my opinion still is, a totally logical response to the problem of death. 


\section{Acknowledgment}

The author is grateful to Ian Taylor and Rodney Hoare for their help during the drafting and manuscript stages of this work respectively.

\section{References}

Douglas, J.D. (Ed.). (1982). New Bible dictionary. Wheaton, IL: Tyndale.

Hoare, R. (1984). A piece of cloth: The Turin shroud investigated. Wellingborough, England: Aquarian Press. 